Joanna Zach ํำ https://orcid.org/0000-0002-7425-3540

Jagiellonian University joanna.zach@uj.edu.pl

\title{
The Reconstruction of a Poet: On the Margins of the Biography of Zbigniew Herbert
}

\author{
(Andrzej Franaszek, Herbert. Biografia, Vol. 1: Niepokój, Vol. 2: Pan \\ Cogito, Wydawnictwo Znak, Kraków 2018, pp. 1920) ${ }^{1}$
}

Andrzej Franaszek spent a lot of time preparing to write this book. His biography of Zbigniew Herbert was published twenty years after Ciemne źródto, Franaszek's essay on suffering in Herbert's oeuvre. "Franaszek proves that Herbert's voice emerges from the depths of desolation and through human weakness," critic Piotr Śliwiński wrote about his debut. ${ }^{2}$ Already here there appeared threads that the author would explore in greater depth in his later works: questions about the spiritual potential of boundary situations and the contrast between the dark side of life and the "brightness" of poetry. Does it befit one to speak of life in our postmodern era? The distance that separates thinking about literature from popular biographical accounts appears impossible to overcome. Perhaps that is why the most serious challenge is the return to the relationship between the poem and the specific human being who is its author. In the preface to his second book, whose subtitle is 44 szkice o literaturze i przygodach

${ }^{1}$ Originally published in Konteksty Kultury 2018, vol. 15, no. 1 (the Polish title: "Rekonstrukcja poety. Na marginesie Biografii Zbigniewa Herberta (Andrzej Franaszek, Herbert. Biografia, t. 1: Niepokój, t. 2: Pan Cogito, Wydawnictwo Znak, Kraków 2018, ss. 1920)").

2 A. Franaszek, Ciemne źródto (O twórczości Zbigniewa Herberta), London 1998; $2^{\text {nd }}$ ed.: Ciemne źródto. Esej o cierpieniu w twórczości Zbigniewa Herberta, Kraków 2008 (the quote from Piotr Śliwiński comes from the fourth pages of the jacket, $2^{\text {nd }}$ ed.). 
duszy ("Forty-Four Sketches on Literature and Adventures of the Soul"), Andrzej Franaszek confesses:

I trust that the most beautifully, most fully meaningful meeting with the text occurs when (...) someone else's thinking becomes personally important to us, engaging us down to our depths, broadening our world or also allowing to better feel, think through, and name what we ourselves had experienced; when reading is just as much building oneself as an attempt at passing the bridge to another human, a lesson of a compassionate imagination. ${ }^{3}$

I interpret Franaszek's book Przepustka zpiekta ("A Pass from Hell”) as the project of criticism that opposes the obviousness of the collapse of the "estate of Polish poetry" as well as the break in the continuity between the spiritual experience, fixed in twentieth century literature, and the sensitivity that permeated it after 1990. Reaching to elementary experiences, studying the "convolution of evil and suffering," we can discover, as the critic argues, a deeper dimension of the symbolic community and expose the hidden kinship between two phenomena that are very far apart from each other. Furthermore, Andrzej Franaszek's works are, as Marian Stala writes, "a manifesto of subjective criticism, subjectively engaged, not hiding one's arguments and passions and, at the same time, is always ready for an encounter with emotions and views presented in the work that is read." ${ }^{4}$

For several years, Andrzej Franaszek has been mostly known as a biographer of Czesław Miłosz. Thus it is worth recalling that his critical attitude was shaped to a significant degree by being in dialogue with Herbert's poetry; reading as "a lesson of a compassionate imagination" is a response to the poetic credo of Herbert, who writes that writing is "the art of empathy, or feeling what others do." Reading as co-experiencing, or even as "co-writing" - when the shape of someone else's experience, impressed onto language, demands repetition - is in equal parts an antiquated, approach and a completely modern one, as it is late modernity that eliminates the obvious distance between the voice of literature and the critical discourse. However, this usually goes hand in hand with bolstering the empowerment of criticism at the cost of breaking, even nullifying, the empowerment of that voice. In Andrzej Franaszek's case, this not only means its full "empowerment," but the rebuilding of the personal relationship

${ }^{3}$ Idem, Przepustka z piekta. 44 szkice o literaturze i przygodach duszy, Kraków 2010, p. 7.

${ }^{4}$ M. Stala, "Lekcja współczującej wyobraźni. Na marginesie 'Przepustki z piekła' Andrzeja Franaszka” [in:] idem, Niepojęte: Jest. Urywki nienapisanej ksiązki o poezji i krytyce, Wrocław 2011, p. 132.

5 See: R. Gorczyńska, "Sztuka empatii. Rozmowa ze Zbigniewem Herbertem," Zeszyty Literackie 1999, vol. 68, pp. 156-165. 
between the reader and the writer, despite the fashionable argument that this relationship is only a myth or utopic ideal.

This leads to the question of what relation this has to biography, be it a biography of Czesław Miłosz or that of Zbigniew Herbert. I would like to above all emphasize that the starting point and basis for these preeminent writers' projects is the "art of reading," the hermeneutics of the literary text, whereas the aim behind the implementation of these projects is a full (to the extent that it is possible) reconstruction of the personality of the human-as-artist, taking into consideration both biographical sources and spiritual experiences whose shape we find in works of literature. Sometimes the spiritual life, which is expressed in poetry, achieves in it such intensity and clarity that it says more about humanity than does biographical research. At times its voices speak with such power that it dictates not only words, but life choices as well. However, poetry and literature are governed by their own distinct laws that one cannot ignore. Furthermore, Herbert, for example, consciously and programmatically wrote "against himself," in opposition to natural impulses and everything that brings humanity down. Perhaps that is even (at least, that is how the poet himself reasoned) a universal principle of every real work of art that is to an equal degree the fruit of talent or genius and internal discipline. T. S. Eliot, with whom Herbert shared a certain kinship, wrote: "the more perfect the artist, the more completely separate in him will be the man who suffers and the mind which creates." 6 How, then, can we track these connections between life and art that allow for the consolidation of the image of the human as the artist? This is the difficulty; this is where the greatest challenge is found. Wacław Oszajca once wrote about Miłosz that "he is his poetry, despite or rather thanks to the aspects of his biography that could contradict the truth of that poetry."7 Even if he or she shares a similar conviction, the biographer must put great effort into at least partially substantiating it.

Franaszek's book Herbert. Biografia is the most extensive and richest, with regards to source material, publication on the life of Zbigniew Herbert. It is also the most complete overview of his oeuvre. The first volume, titled Niepokój ("Anxiety"), contains 860 pages of text and encompasses the period between 1924 and 1963. The second volume, Pan Cogito ("Mr. Cogito"), consists of

6 T.S. Eliot, "Tradition and the Individual Talent," Poetry Foundation, https://www.poetryfoundation.org/articles/69400/tradition-and-the-individual-talent, accessed: 30.04.2019.

7 W. Oszajca, SJ, "Sięgać po niemożliwe” [in:] Czestaw Mitosz. In Memoriam, ed. J. Gromek, Kraków 2004, p. 89. 
956 pages (including the bibliography) and concerns the period from 1963 to 1998. The scope of Franaszek's investigation of archival sources attests to the scale of this effort. Herbert never wrote an autobiography, nor was he the subject of a book-length interview; he did not even regularly write a diary. He did, however, leave behind an enormous amount of notes (often enigmatic, undated entries) and an abundant correspondence that is scattered across various archives. A critical compilation of these sources, an evaluation of their intellectual value, and, finally, the reconstruction of specific areas of Herbert's biography is, today, after the "archival revolution," a separate area of research. Everything that brings one closer to the truth simultaneously deforms it, while every revelation further obscures some dark fields. Finally, there is the central question: how, in the polyphony of voices, in the flood of sometimes contradictory testimonies, can one establish a narrative? Already in his biography of Miłosz, Franaszek succeeded in achieving a rare balance between his personal, engaged narration and a dependable and, one would like to say, impartial presentation of sources. Can empathy be impartial? Is it not inevitably linked to the need to defend the protagonist? Both of Franaszek's books convince me that this is a matter of the scale by which one measures the potential of humanity, a measure of the selection of the perspective through which we want to understand human life. If this perspective is sufficiently capacious, if we are aware of the limitations imposed by cultural models, it is easier to evade writing a defense, which is, of course, the opposite of judgment. In other words, this means a vision of humanity that leaves room for both greatness and pettiness, that does not demand greatness to be flawless, refusing to confuse it with virtue. The Polish cultural norm is, in this regard, especially restrictive. In various spheres, Miłosz consciously resisted it; it is another matter that he did not do so very effectively. Meanwhile, Herbert, as Franaszek brilliantly shows, adapted his automythology to the requirements of national mythology.

To repeat, Andrzej Franaszek's monograph reconstructs the materials he had found in the archives very scrupulously. They include invaluable findings that present the poet's work and personality in a new light (for example, unknown drafts of important writings, ${ }^{8}$ anonymous texts by Herbert published in émigré journals, or Aleksander Gella's report on the "row" at the Carpenters' home).? From a certain point of view, the book could be called a painstaking arrangement of source materials supplemented by historical-literary commentary. (By

${ }^{8}$ Here, it is worth mentioning variants of "Episode in a Library," whose chronological juxtaposition not only gives insight into the creative process but also reveals a certain intimate trait of Herbert's personality.

9 I am referring to the famous dinner at the home of Bogdana and John Carpenter (July 11, 1968, in Berkeley), during which Zbigniew Herbert and Czesław Miłosz drastically differed in their assessment of the Warsaw Uprising and the Home Army. 
the way, it was Miłosz's dream to open a debate on essential and sensitive matters with a book consisting of quotes and commentary; that is how his essay Cztowiek wśród skorpionów ["Man Among Scorpions"] is written and how his anthology Wyprawa w dwudziestolecie ["A Journey into the Interwar Period"] is thought out). Furthermore - I write this with full conviction - this biography of Herbert is an enormous literary accomplishment. Franaszek succeeds in reconciling reliability, "conscientiousness in the face of sources," with an ambitious artistic project that develops on many levels: the core of the biographical narrative is encased in numerous themes that broaden its perspective, and the titles of specific chapters create the outline of a separate story "Ostatnia Aleksandria" ["The Last Alexandria"], "Obrońca smoków" ["Defender of Dragons"], "Lekcja łaciny..." [“A Latin Lesson”], "Orfeusz i torf” ["Orpheus and Peat"]). The book opens and closes with a description of Herbert's workspace; the eye of the camera scans from object to object, pausing on book titles, military memorabilia, and collections of stones. The library, Andrzej Franaszek writes, "is like the story of the life and soul of its owner, of his aesthetic and moral choices, travels, friendships, and failures." ${ }^{10}$ The lines of a poem flare up for a moment: "If he had any sense of identity it was with a stone/ a sandstone not too porous a light luminous gray." 11

Many controversies related to Herbert's life have arisen. This is partly a result of Joanna Siedlecka's biography of him (Pan od poezji, Warsaw 2002). In the style of a journalistic investigation, Siedlecka questioned the poet's alleged participation in the underground. This is just one of many of Siedlecka's "sensational" reports, but it added weight to the book's "scrutinizing" nature. After the publication of "Mr. Cogito," the image of Herbert as an "unshakeable poet" became part of the collective ethos; in the early 1990s, it was the subject of political manipulations. The selection of Herbert as teacher and master, especially for young readers from the Solidarity generation who were just entering adult life, had an axiological dimension; it signified the choice of a specific attitude and definitive vision of Polish history. We should add that this was why part of the young literary milieu rejected his poetry after 1990 . Herbert was fully aware that he had created a certain poetic personality that was getting back at him. He frequently spoke of the dissonance between art and life, although he considered striving for a better "I" that is realized in writing to be an essential part of the human personality ("Humanity is what

\footnotetext{
10 A. Franaszek, Herbert. Biografia, vol. 1: Niepokój, Kraków 2018, p. 14.

${ }^{11}$ Ibid., p. 13.
} 
it would like to be: the amalgamation of meat and dreams"). ${ }^{12}$ However, he found himself in a unique situation, one that had been created by historical circumstances and Polish mythology, one that requires a person to "shoot at the enemy with diamonds." ${ }^{13}$ In a conversation with Renata Gorczyńska, he said: "The author must stand behind his poems. This is the harsh fate of the Polish poet, who is slave to what he has said. He cannot say: 'Let the poets have a moment of joy, or else your world will perish."' ${ }^{14}$ The problem that we touch upon here is not reduced to the (otherwise obvious) difference between poetic autocreation and the figure of the artist. The question is that in various statements Herbert implied, and sometimes even said directly, that in the 1940s he was engaged in the efforts of the armed underground. The sources do not support these claims; in fact, they downright contradict them. It cannot be denied that the author of "Mr. Cogito" entangled himself in mystification.

"The problem of Herbert and his poetry," Barbara Toruńczyk writes, "is the problem that we have today with our own identity." 15 Although this sentence is not relevant to the topic I bring up, it could shine light on various parts of Franaszek's narrative. In this case, he is more interested in cultural conditions than in psychological mechanisms; specifically, in the "thanatocentric" orientation of Polish culture and the type of relationship between the individual and the community ingrained in it since the Romantic period: "Without a doubt, much more important than finding the protagonist guilty of confabulation is the desire to understand a man who was a brilliant poet, but perhaps wanted or even thought that he should be; he believed that others expected this of him - to be someone else," Franaszek writes. ${ }^{16}$

I find it unlikely that this argument will be convincing to Herbert's "scrutinizers." They will read Franaszek's work selectively and find in it rich material that is "unfavorable" for the poet. Personal and family problems, the topic of mental illness, and the intellectual condition of the poet in the last years of his life all suggest that he had a volatile personality, one that was internally conflicted and "fractured." For me, Herbert's life as narrated by Franaszek is a story full of suffering, private and public misfortunes, difficult choices, and painful entanglements. It is also, however, the story of an exceptional, and in some sense superhuman spiritual struggle thanks to which the poet in essence transcends himself. Finally, this is a book about the twentieth century, a period with which we continue to have a very difficult

12 “Ze Zbigniewem Herbertem rozmawia ksiądz S. Janusz Pasierb” [in:] Herbert nieznany. Rozmowy, Warszawa 2008, p. 62.

13 See: A. Franaszek, Ciemne źródto..., $2^{\text {nd }}$ ed., op. cit., p. 246.

${ }_{14}$ R. Gorczyńska, op. cit., p. 158.

15 B. Toruńczyk, "Dukt pisma, dukt pamięci," Zeszyty Literackie 1999, vol. 4, p. 179.

${ }^{16}$ A. Franaszek, Herbert. Biografia, vol. 1, op. cit., p. 205. 
relationship; defense mechanisms and internal historical-political divisions are at work here. Herbert's life and work are an area of great tensions, one that has been sculpted by the currents of his age. That is also why every chapter of this biography presents an opportunity for a broader look at the culture of the past century.

I would say that, as the author of biographies of Miłosz and Herbert, Andrzej Franaszek has spent years setting up a narrative about the most important, most emblematic figures of the "Polish destiny," ones that are at the same time familiar and significant in the horizon of world literature. He above all tries to liberate his protagonists from geopolitical limitations and present their attitudes as comprehensively as possible. Franaszek presents these figures as "great, solitary chess pieces, sculpted not by the hands of an artisan, but by years of experiences, accomplishments, disappointments, conquests, and sufferings." ${ }^{17}$ This cannot be done without a vast background, without the context of twentieth century history, aesthetics, and politics. Likewise, this is impossible without understanding internal conflicts within Polish society that return in important episodes of their biographies, such as the first "frontal confrontation" of the poets in 1968. Franaszek writes:

Essentially, two Polands met. One was more liberal and skeptical, critical of its own tradition, especially of its main Catholic and center-right current. The other was not necessarily nationalistic, but strongly attached to the imponderable, sometimes accepting criticism traumatically, convinced above all that one should not 'defile one's one nest' and account to foreigners. At the same time, the words 'right' and 'left' had different meanings for the two poets. ${ }^{18}$

It is not difficult to notice the relevance of these reflections. At the same time, the story of the relationship between Herbert and Miłosz transcends here what has been discussed before. It encompasses their different visions of European culture (the poets shared a conviction about the value of the dialogue of cultures and languages, while their attitude towards Russia is radically different), the ideological dispute and its reception, and the paradoxical mix of mutual respect and affection with attachment to irreconcilable. Franaszek does not limit himself to the presentation of source materials, but he does not place himself on either side of the conflict; he does not walk "between the blade of powerful fencers." He tries to understand their attitudes in the context of their entire lives. The biographer writes:

Although Miłosz compared himself to the youngest, naive brother from folk tales who chooses a different path but ultimately is victorious, he had a certain tactical

17 See: idem, Przepustka z piekta, op. cit., p. 7.

18 A. Franaszek, Herbert. Biografia, Vol. 2: Pan Cogito, Kraków 2018, p. 251. 
sense, one can say, that his internal constitution was disposed towards victory, somewhat the opposite as in the case of the sometimes auto-destructive and psychologically weaker Herbert. ${ }^{19}$

If from this enormous biography of Herbert, replete with details as well as previously unknown facts and testimonies found in archives, I were to select the single trait that at the deepest levels makes it possible to integrate (understand) his personality, it would be this "disposition towards failure." In my opinion, it is not coincidental that this trait becomes most evident when confronted with Miłosz's personality. "Elegy of Fortinbras" is at the beginning of their poetic dialogue. It seems that behind the curtain of irony Herbert remains, until the end and above all, the guardian of words that "what can they do what can they do prince." He will remain the most illustrious disciple of Henryk Elzenberg, whose essay "Brutus czyli przekleństwo cnoty" ("Brutus, or the Curse of Virtue") is recalled by Andrzej Franaszek on the pages of Ciemne źródto ("The Dark Source"): "Instead of this awareness of power and confidence in it," we read, "which is characteristic of born victors, there is in him [in Brutus - J.Z.] with regards to the work undertaken in the future a restraint so great, that it becomes a disposition towards failure." ${ }^{20}$ In the last years of his life, in response to Miłosz's A Year of the Hunter, Herbert worked on an unfortunately unfinished book with the characteristic title: The Year of the Lamb. Up until the end, he would be unable to untie the spiritual knot that bound him to Miłosz: a bond encompassing poetry, rivalry, traumas, and a difficult "strange love." For himself, as recalled by Franaszek's Photograph, he chose the role of the ritual victim.

Andrzej Franaszek writes:

There is nothing simpler than to say that a biography should be honest. In practice, this means thousands of minor decisions: at what point to end a quotation, what should be hidden between brackets with an ellipsis, what context should be added, how to place the different accents, and what should ultimately be avoided. We are tempted by the power of the narrator or, at least, the power of the story; information learned once exhorts that we bring it up. Almost each of them can demand interpretation, commentaries, qualifications, another particle of a sentence that after each comma beginning with the word 'however.' History

19 Ibid., p. 250.

${ }^{20}$ Idem, Ciemne źródto..., $2^{\text {nd }}$ ed., op. cit., p. 77. 
does not even become a maze, but rather a garden with diverging paths. Most, however, have to be abandoned so that the reader can in fact get across and survive this reading. ${ }^{21}$

We should feel transformed upon leaving this garden.

Translated by Filip Mazurczak

${ }^{21}$ Idem, Herbert. Biografia, Vol. 2: op. cit., p. 831. 